\title{
Hypolytrum (Cyperaceae): taxonomic and nomenclatural notes, geographical distribution and conservation status of Neotropical species
}

\author{
Marccus Alves ${ }^{1,4}$, Maria das Gracas Lapa Wanderley $^{2} \&$ William Wayt Thomas $^{3}$
}

\begin{abstract}
(Hypolytrum (Cyperaceae): taxonomic and nomenclatural notes, geographical distribution and conservation status of Neotropical species.) Hypolytrum (Mapanioideae) is a medium-size and Pantropical genus of Cyperaceae, closely related to Mapania, Principina, and Scirpodendron. In the Neotropics, it is found from southern Mexico to southern Brazil where it grows in the Atlantic and Amazon Forests and Cerrado vegetation. Most of the species are found in the humid and shady understory of forested habitats. Twenty-nine species are confirmed, nine of which are considered narrow-endemics and one is poorly known. Twelve species are classified under the conservation status of Critically Endangered or Vulnerable. A total of 130 types (holotypes, isotypes, lectotypes and isolectotypes) and 42 photos of types were checked and confirmed, and 22 synonyms were verified and accepted. Information about geographic distribution including new occurrences, habitat and diagnostic characters are also provided.
\end{abstract}

Key words: Atlantic Forest, Amazon Forest, Neotropics, Mapania, Mapanioideae

\section{Introduction}

Hypolytrum Rich. is a medium-sized Pantropical genus of Cyperaceae, mainly associated with the understory of forested areas but with some species from savanna-like vegetation (Goetghebeur 1998; Alves 2003). Almost 60 valid names were cited for the genus by Govaerts et al. (2007), and ca. $50 \%$ of them have been accepted by Alves et al. $(2009,2014)$ for Brazil. This highlights the country's importance as a major player in the diversity and conservation as well as the understanding of the phylogeny and character evolution of this genus and allied groups.

Hypolytrum is placed in the subfamily Mapanioideae and a morphological alliance with Mapania Aubl., Principina Uittien and Scirpiodendron Zipp. ex Kurz. has been suggested by Goetghebeur (1998) and Bruhl (1995). Phylogenies have shown high support for Mapanioideae combined with some morphological synapomorphies, but no clear evidence of the relationship among the four genera has yet been found (Muasya et al. 1998;
2000, 2009; Alves 2003; Simpson et al. 2003, 2007). Members of Mapanioideae (which comprises less than $3 \%$ of the species of Cyperaceae) are clearly distinguished from members of other subfamilies by the flower arrangement, which has a controversial terminology (Simpson 1992; Goetghebeur 1998; Alves et al. 2001).

Hypolytrum is recognized as having 2 (rarely 3 ), connate to free floral bracts (= hypogyneous scales, sensu Goetghebeur 1998), 2 styles and lack of silica bodies in the leaves (Koyama 1970; Goethghebeur 1998; Alves et al. 2002c; Alves 2003) and is organized in 4-3 sections (Koyama 1970; Alves 2003). Plants are delicate to robust (0.2-2.3m tall) with sessile or pseudopetiolate leaves, central or lateral scapes (up to 14 per specimen or shoot of the rhizome), single spike to branched (up to $6^{\text {th }}$ order) inflorescence, clustered or isolated spikes (sometimes called spikelets) on the axis, and smooth to wrinkled, blackish to reddish achenes, with or without dots (Koyama 1970; Goethghebeur 1998; Alves 2003). Alves et al. (2001) indicated that flowers are unisexual and organized in spicoids

\footnotetext{
${ }^{1}$ Universidade Federal de Pernambuco, Depto. Botânica, Av. Moraes Rego s/n, 51930-630, Recife, PE, Brazil. Temporary address: Herbarium Senckenbergianum, Frankfurt am Main, Germany, 60-325.

${ }^{2}$ Instituto de Botânica de São Paulo, Curadoria do Herbário, Av. Miguel Estéfano 3687, C.P.68041, 04045-972, São Paulo, SP, Brazil. gracaw@me.com

${ }^{3}$ The New York Botanical Garden, Bronx, New York, 10458-5126, USA. wthomas@nybg.org

${ }^{4}$ Author for correspondence: alves.marccus@gmail.com
} 
and each one has male and female naked flowers, surrounded by 2 floral bracts and an outer spicoid bract. A spike is composed of several congested spicoids and the inflorescence can have only one to hundreds of spikes. Because of this complex arrangement (flowers in spicoids, spicoids in spikes and spikes in inflorescences), it can also be called synflorescence.

For the Neotropical area, besides the taxonomic studies and new species described in Hypolytrum and Mapania, which is the only closely related genus that also occurs on the American continent (Koyama 1969, 1970; Simpson 1992, 1996; Alves 2003; Alves et al. 2002a, 2002b, 2004), important morphological evidence, evolutionary interpretations and information about diversity and geographical distribution have been published (Koyama 1966; Alves et al. 2000, 2002c, 2003, 2009, 2014; Coan et al. 2008, 2010; Rodrigues \& Estelita 2009; Silva et al. 2014).

The approach employed here provides updated information about species of Hypolytrum and their related names and types. Additionally, information on geographical distribution and habitat, conservation status based on categories of the IUCN (2012) and some diagnostic characters are also presented.

\section{Methods}

This study made use of extensive collections, which have been carried out by the authors over the last 15 years. They include samples from field expeditions all over Brazil, but especially along the coastal Atlantic Forest from the state of Pernambuco to Santa Catarina states and some areas in the Amazon Forest in the states of Acre, Amazonas, Roraima, and Tocantins states.

Samples collected have been primarily deposited at the UFP herbarium, with duplicates at CEPEC, INPA, NY, RB, SP, and SPF, among others. In addition, morphological and geographical data were collected from samples examined at the following herbaria: A, AAU, ALCB, ASE, B, BH, BHCB, BKL, BM, BOLO, C, CAY, CEN, CEPEC, CESJ, CVRD, DOV, EAC, EAN, F, FLOR, FR, FURB, G, GH, GOET, GUA, HB, HBG, HBR, HPZ, HRCB, HRR, HST, HTO, HUEFS, HUESB, IAC, IAN, IBGE, INPA, IPA, JPB, K, M, MAC, MBM, MBML, MG, MICH, MO, NY, P, PAD, PEUFR, PH, PMSP, R, RB, RBR, RFA, RUSU, S, SCZ, SI, SP, SPF, SPSF, STRI, TEPB, UB, UFG, UFP, UPCB, US, VIES, W, and WU.
Geographic distribution is based on the collections studied at the herbaria mentioned above and field trips in addition to information published by Alves (2003), Alves et al. (2003, 2009, 2014), Camelbecke et al. (2007), GómezLaurito (1994, 2003) and Simpson (1998). Conservation status follows the criteria adopted by the IUCN (2012). Under the "representative material examined", three samples are cited to express the range of distribution, habitats and morphological variation of each species.

\section{Results and Discussion}

Hypolytrum is here confirmed as a more diverse genus in the Neotropics with 29 of the 58 species cited by Govaerts et al. (2007). It mainly occurs in the tropical areas from northern Central America (state of Veracruz-Llav, Mexico) to South America with a short extension into the subtropics (state of Santa Catarina, Brazil) (Alves et al. 2003; Alves et al. 2009, 2014; Camelbecke et al. 2003; Gómez-Laurito 1994, 2003; Simpson 1998). It is often found in the understory of humid and shady forests that can be seasonally or permanently flooded or not subject to flooding. Some species are restricted to open vegetation habitats, such as rocky outcrops, grasslands on sandy soils or transition areas from dry-forest to savanna-like vegetation. Among the species found in the Neotropics, six of them are found in open areas: H. bahiense M. Alves \& W.W. Thomas, H. leptocalamum M. Alves \& W.W. Thomas, H. paraensis M. Alves \& W.W. Thomas, H. pulchrum (Rudge) H. Pfeiff., H. rigens Nees, and $H$. supervacuum C.B. Clarke.

Some species have intense vegetative growth and can be dominant in some patches of forest such as $H$. schraderianum Nees and $H$. verticillatum $\mathrm{T}$. Koyama while others can be very rare and known from a few (type-locality and surroundings) and small populations such as $H$. amorimii M. Alves \& W.W. Thomas, $H$. espiritosantense M. Alves \& W.W. Thomas, $H$. glaziovii Boeck., H. glomerulatum M. Alves \& W.W. Thomas, H. jardimii M. Alves \& W.W. Thomas, H. lucennoi M. Alves \& W.W. Thomas, $H$. pallidiceps S. Hooper \& T. Koyama, and $H$. paraense M. Alves \& W.W. Thomas.

Three species are found in Central America: H. amplissimum M. Alves \& W.W. Thomas, $H$. longifolium (Rich.) Nees, and $H$. nicaraguense Liebm. and 28 are found in South America, 
which is a key area to the diversity of the genus as a whole (Alves et al. 2003). Hypolytrum amplissimum, endemic to the Isla del Cocos (Costa Rica), is the only species that does not occur in South America (Gómez-Laurito 2003).

The Amazon Forest and associated ecosystems, such as "tepuis" and coastal and high-elevation grasslands, house 16 species and most of them are restricted to the area, except for $H$. pulchrum and H. schraderianum, which are also found in the Atlantic Forest. The Atlantic Forest and associated ecosystems such as coastal sand dunes, "restingas", and sandy soil coastal "tabuleiros" hold 11 species and most of them are narrow-endemics. Only one species, H. rigens, grows in Cerrado vegetation.

Brazil has the highest diversity with almost all the species from South America represented in the country except for $H$. pallidiceps, which is known from the Guyana side of the Roraima Mountains on the border between Brazil and Venezuela. It is followed in number of species by Venezuela, Guyana, Colombia, French Guiana and Suriname. The most diverse area in the Amazon Basin is the Guayana Shield and surrounding areas (Simpson 1998; Alves et al. 2003; Camelbecke et al. 2007).

The Atlantic Forest is clearly the center of diversity for narrow-endemic species of the genus in the Neotropics combined with few and small known populations $-H$. amorimii, $H$. bahiense, $H$. espiritosantense, $H$. glaziovii, H. glomerulatum, $H$. jardimii, and H. lucennoi. Hypolytrum paraense in Serra dos Carajás (Pará, Brazil) and H. amplissimum in Isla del Coco (Puntarenas, Costa Rica) are examples of narrow-endemism in the genus outside the Atlantic Forest. This condition is clearly a major reason to have nine species under CR (Critically Endangered) and three under VU (Vulnerable) conservation status.

In general, most of the species can be easily recognized by a combination of characters such as the habit (small and delicate vs. tall and robust plants), leaves (sessile vs. pseudopetiolate, bullate vs. smooth, and width), scape (axillary vs. central), inflorescence (capitate vs. branched, and conical vs. pyramidal shape), spike arrangement (isolated vs. clustered), floral bract (connate vs. free, and strongly vs. lightly scabrid keels), and achenes (non-dotted vs. reddish-dotted, smooth vs. wrinkled surface, contracted vs. spongy apex, and length).
Some species are morphologically variable across their wide geographical distribution and variety of habitats, making their correct identification sometimes difficult (Alves 2003). More studies using genetic population analyses among $H$. leptocalamum, $H$. pulchrum and $H$. supervacuum and between $H$. amplissimum and H. amplum would provide a better understanding of their taxonomic limits.

Koyama (1970) cited four sections within Hypolytrum: $H$. sect Bullata T. Koyama, $H$. sect. Lancifolia Nelmes, $H$. sect. Hypolytrum, and $H$. sect. Scaposa C.B. Clarke. However, Alves (2003) based on morphological analyses proposed $H$. sect. Bullata as a new synonym under $H$. sect. Lancifolia, which is followed here.

Hypolytrum sect. Lancifolia comprises plants with pseudopetiolate leaves and a central scape (one inflorescence axis per specimen or shoot from the rhizome). In the Neotropics, it is restricted to South America and represented by four species: $H$. amorimii, $H$. bullatum, and $H$. jardimii (in Atlantic Forest) and H. stemonifolium T. Koyama (in Amazon Forest).

Hypolytrum sect. Scaposa comprises plants with lateral scapes (from 2-14 per specimen or shoot from the rhizome) and leaves can be sessile or pseudopetiolate. In the Neotropics, it is restricted to the Amazon Forest in South America with four species: H. jenmanii C.B. Clarke emend Uittien, H. nudum C.B. Clarke, H. strictum Poepp. $\&$ Kunth, and $H$. spongiosum T. Koyama.

And finally, $H$. sect. Hypolytrum, which is the richest in species and most widespread, includes plants with a central scape and sessile leaves and is represented by 21 species in the Neotropics (it also grows in Africa and southeastern Asia and Australia - Govaerts et al. 2007). It is the most widely distributed section in the Neotropics, with occurrence in Central and South America in Cerrado and Amazon and Atlantic Forests.

In summary, this work updates the current knowledge of the diversity and geographic distribution of the genus with 29 species to the Neotropics, eight of them confirmed as endemic to the Brazilian Atlantic Forest, one of the hotspots of global biodiversity (Mittermeier et al. 2005). Additionally, 130 types (holotypes, isotypes, lectotypes and isolectotypes) and 42 photos of types were examined and confirmed, and 22 synonyms were verified and accepted. 
1. Hypolytrum amorimii $\mathrm{M}$. Alves \& W.W. Thomas, Brittonia 54(2): 124. 2002. Type: Brazil. Espírito Santo, Cariaciaca, Reserva Biológica de Duas Bocas, 1.VI.2000, M. Alves, G. Sousa \& M. Gomes 1943 (holotype MBML!, isotypes NY!, SP!, UFP!).

Endemic to Brazil and restricted to the central part of the Atlantic Forest, usually in very shady and humid areas. It is recorded only to the state of Espírito Santo (Brazil) and considered CR (Critically Endangered) based on the small area of occurrence (only known from the type-locality) and very small populations.

Hypolytrum amorimii can be recognized by the pseudopetiolate, purple to dark-reddish leaves on the abaxial surface and long (42-72 cm long), central and curved scape.

Representative material examined: BRAZIL. Espírito Santo: Cariacica, Reserva Biológica de Duas Bocas, 6.III.2001, M. Alves et al. 2319 (CEPEC, MBML, NY, SP, UB, UFP), 21.X.2008, C. Fraga et al. 2178 (CEPEC, MBML, RB, UFP, UPCB), 15.XII.2008, A. Amorim et al. 7119 (CEPEC, UFP).

2. Hypolytrum amplissimum M. Alves \& W.W. Thomas, Feddes Repert. 133: 261. 2002. Type: Costa Rica. Puntarenas, Cocos Island, Chatam Bay, 8.III.1964, L. Fournier 293 (holotype NY!, isotype DAV).

It is endemic to shady and humid areas of lowland forest in the island of Cocos (Puntarenas, Costa Rica) in the Pacific Ocean and it is considered CR (Critically Endangered) based on the limited area of occurrence.

Hypolytrum amplissimum is morphologically related to $H$. amplum and $H$. schraderianum, but can be differenciated by the length of the tectriz bract (50-69 $\mathrm{cm}$ long) and the spicoid bract (1.9$3.4 \mathrm{~mm}$ long) besides having 2 floral bracts free. It was cited by Gómez-Laurito (2003) e Govaerts et al. (2007) as a synonym of $H$. amplum.

Representative material examined: COSTA RICA. Puntarenas: Isla del Coco, Chatham Bay, 11.IV.1965, A. Jimenez 3144 (F, MO, NY), 31.VII.1981, J. GómezLaurito 6922 (MO), 1.XI.1997, L. González 638 (MO).

3. Hypolytrum amplum Poepp. \& Kunth in Kunth, Enum. Pl. 2: 272. 1837. Type: Brazil. (Amazonas), prope Ega, ad fluvium Amazonum, s.d., Poeppig s.n. (lectotype F! - designated by Alves et al. 2004). $=H$. costatum Steud., Synops. Pl. Glumac. 2: 133 . 1855. Type: Suriname. S.loc., s.d., Hostmann 1168 (holotype P!, isotypes BM!, G!, K!, P!), non $H$. costatum Thw., non $H$. costatum Nelmes.
It is widely distributed in the Amazon Forest in the shady and humid understory of seasonally flooded forests and non-flooded forests up to 400 $\mathrm{m}$ alt (Alves 2003; Alves et al. 2003, 2014). It is recorded from Colombia (Vaupés and Amazonia), Venezuela (Bolivar and Amazonas), Guyana (Pomeron-Supenaan, Cuyuni-Mazaruni, and Potaro-Siparuni), Suriname (no specified locality), French Guiana (Saül), Brazil (Amazonas and Pará), and Peru (Loreto, Amazonas, and San Martin). It is considered LC (Least Concern) based on its wide distribution and large natural populations.

Hypolytrum amplum, H. amplissimum, and H.schraderianum are the most robust species with highly branched inflorescences growing in Central and northern South America. They also share the central scape and sessile leaves. $H$. amplum can be differentiated from the other two species by the length of spike (11-13 mm long), spicoid bracts (2.8-3 $\mathrm{mm}$ long), and floral bracts (2.5-2.8 mm long).

Representative material examined: BRAZIL. Pará: Oriximiná, Rio Trombetas, 4.VII.1980, C. Ferreira et al. 1286 (INPA, MG, MO, NY). GUYANA. CuyuniMazaruni: Kamakuza, Mazurini River, 14.I.1923, J. Cruz 2788 (BM, GH, F, K, MO, NY, PH). PERU. Amazonas: Bagua, Bosque Yamayakat, 5.X.1995, N. Jaramillo \& D. Chamik 829 (MO).

4. Hypolytrum bahiense M. Alves \& W.W. Thomas, Brittonia 54(2): 126. 2002. Type: Brazil. Bahia, Itacaré, Loteamento Marambaia, 20 Sep 2000, W. Thomas, J. Jardim, S. Sant'Anna \& F. Junchum 12183 (holotype CEPEC!, isotypes K!, NY!, SP!, UFP!).

It is another example of narrow endemism to the central part of the Atlantic Forest and limited to some patches of vegetation on sand dunes and hills in a short area along the coast of the state of Bahia, Brazil (Alves 2003; Alves et al. 2003, 2014). Hypolytrum bahiense is often found in the understory of open forests called "restingas" and sandy soil, coastal "tabuleiros", always close to the coast. It is considered CR (Critically Endangered) based on the small area of occurrence, few localities, and very small populations. It is one of the rare species of Cyperaceae with a sweet floral fragrance and is intensely visited by small bees.

Besides the central scape and sessile leaves, it has very narrow leaves $(30-70 \times 0.3-0.4 \mathrm{~cm})$ combined with spike (5-7 mm long) clustered in $1^{\text {st }}$ order branches of the inflorescence. It morphologically resembles $H$. shaerostachyum 
and H. pallidiceps, but these latter two are both restricted to the Amazon Forest, shorter, and with non-dotted and smooth achenes.

Representative material examined: BRAZIL. Bahia: Itacaré, southern coast, 2.IX.1970, T. Santos 1065 (CEPEC, K, NY), road to Ubaitaba, 4.XI.2001, $A$. Amorim et al. 419 (CEPEC, K, NY), Fazenda Capitão, 20.XI.1991, W. Thomas et al. 12749 (CEPEC, K, NY).

5. Hypolytrum bullatum C.B. Clarke, Kew Bull. Addit. Ser. 8: 51. 1908. Type: Brazil. Bahia, s.d., Blanchet n. 3161. (lectotype G!, isolectotypes G!, K!, NY photo!, UFP photo! - designated by Charpin et al. 1993).

= Becquerelia bullata C.B. Clarke \& H. Pfeiff., Feddes Repet. Spec. Nov. Regni Veg. 18: 382. 1922. Type: Brazil. (Bahia), montosis prope Una, Aug 1820, Riedel s.n. (holotype K!, isotypes BM!, C!, F photo!, LE, NY photo!, P!, SI!, US!).

Endemic to Brazil and restricted to the centralnorthern part of the Atlantic Forest usually in shady and humid areas. It is recorded from the states of Pernambuco, Alagoas, Bahia, and Espírito Santo, probably growing also in Sergipe and Paraíba based on the collections made close to the border of these states. It is considered VU (Vulnerable) based on the area of occurrence, few localities in fragmented forest and often medium to small-sized populations in the northern part of its distribution in the states of Alagoas and Pernambuco.

It has a pseudopetiole and central scape, and can be easily recognized by the linear leaves bullate in the middle. Bullate leaves can also be occasionally found in some specimens of $H$. stemonifolium (with elliptical and oblong leaves) and $H$. schraderianum and $H$. sylvaticum both with sessile leaves (Alves et al. 2002c).

Representative material examined: BRAZIL. Alagoas: Murici, Estação Ecológica de Murici, 10.II.2009, A. AlvesAraújo et al. 1139 (UFP). Bahia: Ilhéus, Mata do Estado, 30.I.2000, M. Alves et al. 1866 (CEPEC, IAN, NY, SP, UB, UFP). Pernambuco: São Vicente Férrer, Mata do Estado, 6.XI.1999, M. Alves et al. 1666 (IAN, SI, SP, SPF, UFP).

6. Hypolytrum espiritosantense M. Alves \& W.W. Thomas, Feddes Repert. 113: 263. 2002. Type: Brazil. Espírito Santo, Cariacica, Reserva Biológica de Duas Bocas, 1.VI.2000, M. Alves, G. Sousa \& M. Gomes 1944 (holotype MBML!, isotype NY!).

Endemic to Brazil and restricted to the central part of the Atlantic Forest in very shady and humid areas. It is known only from the type locality in the state of Espírito Santo (Brazil) and is considered
CR (Critically Endangered) based on the area of occurrence and few specimens recorded.

Hypolytrum espiritosantense has a central scape and sessile leaves among the species from the same geographical area (shady and humid submontane and montane forest in Espírito Santo state), sharing the robust habit, central scape and lacking a pseudopetiole as with $H$. schraderianum. It can be distinguished from this latter species by its inflorescence arrangement (cylindrical and clustered vs. pyramidal and lax), number of branches on the basal node (2-4 vs. 8-14), succession of branches (up to $2^{\text {nd }}$ order vs. up to $6^{\text {th }}$ order), basal epipodium length (1.2-1.6 cm long vs. $1.6-6.5 \mathrm{~cm}$ long) and floral bract length (3.9-4 $\mathrm{mm}$ vs. $1.3-2.9 \mathrm{~mm}$ long).

Material examined: BRAZIL. Espírito Santo: Cariacica, Reserva Biológica de Duas Bocas, 24.II.2000, G. Sousa et al. 320 (SP, UFP).

7. Hypolytrum glaziovii Boeck., Flora 63: 438. 1880. Type: Brazil. Rio de Janeiro, s.d., Glaziou 11655 (lectotype C!, isolectotypes C!, F photo!, GH photo!, INPA photo!, K!, NY photo!, P!, US photo! - designated by Alves et al. 2004).

Endemic and narrow-restricted to some populations in very shady and humid slopes of the central part of the Atlantic Forest in the state of Rio de Janeiro (Brazil) from 150-600 m alt. It is considered CR (Critically Endangered) based on the small area of occurrence, few localities and very small populations.

It has a central scape and sessile leaves and is easily distinguished by the acuminate leaf apex, tectriz bract (inflorescence bract) $3.5-4 \mathrm{~cm}$ long, clustered inflorescence, and achenes $2.2-3 \mathrm{~mm}$ long, wrinkled and reddish-dotted. It is sympatric with $H$. schraderianum and both species are robust and with long and wide leaves, but while $H$. glaziovii has a clustered inflorescence $H$. schraderianum has highly branched and lax one.

Representative material examined: BRAZIL. Rio de Janeiro: Magé, Estação Ecológica Estadual de Paraíso, 6.XII.1984, G. Martinelli et al. 10585 (RB). Rio de Janeiro, Alto da Boa Vista, 29.I.1924, L. Bailey 720 (NY), Parque Nacional da Floresta da Tijuca, 12.IV.2000, $M$. Alves et al. 1927 (GUA, NY, SP, UFP).

8. Hypolytrum glomerulatum M. Alves \& W.W. Thomas, Feddes Repert. 113: 265. 2002. Type: Brazil. Bahia, Boa Nova, Fazenda São José, 14 Oct 2000, W. Thomas, J. Jardim \& S. Sant'Anna 12268 (holotype CEPEC!, isotypes K!, NY!). 
It is a narrow-endemic species. It is found in a small and highly diverse area of the central part of the Atlantic Forest (state of Bahia, Brazil) where in ca. $10,000 \mathrm{~km}^{2}$ also grow $H$. bahiense, H. bullatum, $H$. glomeratum, $H$. jardimii, and $H$. schraderianum. The species is found on slopes of shady and humid submontane forest (850-1,000 m alt.) and it is considered CR (Critically Endangered) based on the restricted area of occurrence (known only from the type-locality) and very small populations.

Hypolytrum glomerulatum has a central scape and sessile leaves and shares, among the species from the same geographical area, a robust habit with $H$. lucennoi and $H$. schraderianum but differs by the conical shape of its inflorescence (vs. pyramidal shape) and clearly larger achenes (2.8-3 $\times 2.1 \mathrm{~mm})$ than found in $H$. verticillatum $(2.1-2.3$ $\times 1.4-1.5 \mathrm{~mm})$ and $H$. bahiense $(1.5-1.7 \times 1-1.2$ $\mathrm{mm})$. It shares clustered spikes at the end of the axes of the $1^{\text {st }}$ order branches of the inflorescence with $H$. bahiense which is a much more slender and shorter plant. Furthermore, it can be distinguished from $H$. bullatum and $H$. jardimii because of its lack of a pseudopetiole.

Material examined: BRAZIL. Bahia. Arataca: Serra da Lontra, Itatigui, 17.III.2005, P. Fiaschi et al. 2820 (CEPEC).

9. Hypolytrum jardimii M. Alves \& W.W. Thomas, Brittonia 54(2): 128 2002. Type: Brazil. Bahia, Uruçuca, Fazenda Catitú, 3.II.2000, M. Alves, W. Thomas, J. Jardim, S. Ant'Anna \& B. Torker 1915 (holotype CEPEC!, isotypes NY!, UFP!).

Narrow-endemic to the central part of the Atlantic Forest (state of Bahia, Brazil) as are $H$. bahiense and H. glomerulatum. Hypolytrum jardimii is often found in shady and humid understory and close to streams. It is considered CR (Critically Endangered) based on the small area of occurrence, few localities and very small populations.

The species has pseudopetiolate leaves and a central scape, being recognized by the oblong to seldom linear leaves $(14-62 \times 2-5.7 \mathrm{~cm})$ with acuminate apex and a strongly scabrid keel of the floral bracts.

Representative material examined: BRAZIL. Bahia: Camamú, Fazenda Zumbi dos Palmares, 22.X.2000, J. Jardim et al. 2763 (CEPEC, HUEFS, NY); Itacaré, Fazenda Boa Esperança, 23.III.2000, W. Thomas et al. 12091 (CEPEC, K, NY, RB); Uruçuca, Reserva Biológica da Serra do Conduru, M. Alves et al. 1960 (CEPEC, IAN, NY, SI, SP, UFP).
10. Hypolytrum jenmanii C.B. Clarke emend Uittien, Kew Bull. Add. Ser. 8: 49. 1908. Type: Guyana. Pomeroon, im Thurn from Waine Falls, s.d., Jenman 1944 (lectotype: K!, isolectotypes: K!, NY photo!, designated by Uittien, 1925).

$=H$. hoppioides C.B.Clarke, Kew Bull. Add. Ser. 8: 51. 1908. Type: Brazil. Pará, Rio Capim, s.d., Huber 888 (holotype MG!, isotypes INPA photo!, SI photo!).

$=H$. jenmanii var. serratifolium Uittien in Pulle, Recueil Trav. Bot. Néerl. 22: 344. 1924. H. jenmanii subsp. serratifolium (Uittien) T. Koyama. Mem. N.Y. Bot. Gard. 17(1): 70. 1967. Type: Guyana. (Mazaruni River), (Aug 1889), Jenman 6118 (holotype K!, isotypes NY photo!, US photo!).

Endemic to north-eastern South America in the Amazon Forest. It is well collected and found in non-flooded forests and in transitional areas from forest to savanna vegetation at 500-750 or seldom up to $1,000 \mathrm{~m}$ alt. Venezuela (Delta Amacuro and Bolivar), Guyana (Cuyuni-Mazaruni, Upper Demerara-Berbice and Potaro-Siparuni), Suriname (Nickerie, Marowijne and Brokopondo), French Guiana (Saint-Laurent Du Maroni and Cayenne), and Brazil (Amapá and Pará). It is considered LC (Least Concern) based on the area of occurrence and the size of its natural populations.

Hypolytrum jenmanii is easily recognized by the lateral (axillary) scapes in numbers from 2-3 to 12 in each specimen (or shoot of the rhizome). It is the only species in the Neotropics with a pseudopetiole, which is not in $H$. sect. Lancifolia because of the axillary scapes. Its pseudopetiole leaves and axillary scape, which are a unique combination among the Neotropical species of the genus.

Representative material examined: BRAZIL. Pará: Portal, Ilha do Breu, 28.IX.1965, G. Prance et al. 1495 (GH, IAN, K, NY, US). FRENCH GUIANA. Saint-Laurent Du Maroni: Saul, Monts la Fumée, 17.VII.1987, S. Mori et al. 18479 (NY). VENEZUELA. Delta Amacuro: Díaz, near to El Palmar, 15.III.1987, G. Aymard 5458 (MO, NY).

11. Hypolytrum laxum Kunth, Enum. Pl. 2: 270. 1837. Type: Brazil. Brasilia Meridionalis, sd., (Martius 127) (lectotype M! - designated by Alves et al. 2004).

$=H$. caespitosum Nees in Mart., Fl. bras. 2(1): 68 . 1842. Type: Brazil. (Amazonas), prov. Fl. Negri, fluvi Japura, s.d., Martius 79 (holotype M!, isotypes M!, F photo!, GH photo!, INPA photo!, US photo!).

Endemic to north-western South America in the Amazon Forest. It is well collected and found 
in flooded and non-flooded forested areas up to $350 \mathrm{~m}$ alt in Colombia (Vaupés and Amazonia), Venezuela (Bolivar and Amazonas), Brazil (Acre and Amazonas), Ecuador (Napo), and Peru (Loreto). It is considered LC (Least Concern) based on the area of occurrence and the known natural populations.

It has a central scape, sessile leaves and is morphologically similar to $H$. sphaerostachyum as which it is often misidentified because of their habits: short plants with short-long spreading rhizomes. Hypolytrum laxum can be recognized by the strongly scabrid keel of the floral bracts (vs. lightly scabrid in H. sphaerostachyum) and reddish-dotted achene with contracted apex (vs. non-dotted and acute).

Representative material examined: BRAZIL. Acre: Cruzeiro do Sul, Igarapé Preto, 29.X.1966, G. Prance et al. 2965 (INPA, K, MG, MO, NY, R, US). ECUADOR. Napo: Rio Napo, Laguna Grande del Cuyabeno, 20.I.1984, S. Laegaard 51111 (AAU, B, COL, K, MO, NY, US). PERU. Loreto: Iquitos, 1.IX.1972, T. Croat et al. 19931 a (MO, PMA).

12. Hypolytrum leptocalamum M. Alves \& W.W. Thomas, Brittonia 54(2): 131. 2002. Type: Guyana. (Cuyuni-Mazaruni), southern Pakaraima Mountains, 24.VIII.1961, B. Maguire \& G. WilsonBrowne 45939A (holotype NY!, isotype NY!).

It is endemic to grasslands of the Guayana Shield from (250-)600-1,500 m alt. on sandy and rocky soil. It is found in Venezuela (Táchira, Bolivar, and Amazonas), Guyana (CuyuniMazaruni and Potaro-Siparuni), and Brazil (Roraima and Amazonas). It is considered LC (Least Concern) based on its distribution and large natural populations.

Hypolytrum leptocalamum has a central scape, sessile leaves and is closely related to $H$. pulchrum. It is mainly differentiated by the lax and $2^{\text {nd }}$ order branched inflorescences and partially connate floral bracts.

Representative material examined: BRAZIL. Roraima: Amajarí, Serra Tepequém, 2.XII.1954, B. Maguire et al. 40142 (K, M, NY, UB, US). GUYANA. Cuyuni-Mazaruni: Pakaraima Mountains, 17.XI.1992, C. Hoffman et al. 3420 (NY, US). VENEZUELA. Amazonas: Cerro Yapacanã, 3.III.1970, J. Steyermark et al. 103048 (NY, US, VEN).

13. Hypolytrum longifolium (Rich.) Nees, Linnaea 9: 288. 1834. Scirpus longifolium Rich., Acta Soc. Hist. Nat. Paris 1: 106. 1792. Type: French Guiana. Cayenne, s.d., D. Le Blond s.n. (holotype: P!).
=H. fuscum Nees in Mart., Fl. bras. 2(1): 67. 1842. Type: Brazil. (Amazonas), prov. Fl. Nigri, ad Rio Negro (Barra), s.d., Martius 82 (holotype M!, isotypes B!, F photo!, GH photo!, M!, NY photo!, US photo!).

= H. irrigum Nees in Mart., Fl. bras. 2(1): 68 . 1842. Type: Brazil. (Amazonas), prov. Fl. Nigri, ad Cataractas fl. Japura, s.d., Martius 16 (holotype M!, isotypes B!, GH photo!, M!, NY photo!).

It is widely distributed in the Amazon Forest up to southern Central America in shady and humid understory of non-flooded forests up to $500 \mathrm{~m}$ alt. It is recorded from Costa Rica (Alajuela and Puntarenas), Colombia (Bolívar, Santander, Vichada, and Vaupés), Trinidad \& Tobago (St. Andrew, St. George, and Victoria), Venezuela (Zulia, Sucre, Lara, Delta Amacuro, Mérida, Bolivar, and Amazonas), Guyana (Cuyuni-Mazaruni, East BerbiceCorentyne, and Upper Tukutu-Upper Esequibo), Suriname (Nickerie, Marowijne, and Brokopondo), French Guiana (Saint-Laurent Du Maroni), Brazil (Amapá, Amazonas, Maranhão, Mato Grosso, Pará, Rondônia, Roraima, and Tocantins), Peru (Loreto), Bolivia (Pando, El Beni), and probably Panama and Nicaragua too. It is considered LC (Least Concern) based on its wide geographic distribution and large natural populations.

Hypolytrum longifolium has a central scape and sessile leaves. It was cited by Koyama (1970) and Govaerts et al. (2007) with four subspecies mainly based on vegetative attributes (H. longifolium subsp. longifolium, H. longifolium subsp. nicaraguense, $H$. longifolium subsp. rubescens, and $H$. longifolium subsp. sylvaticum). All four taxa were considered to be at the species level by Alves et al. (2009, 2014). Alves (2003) added a statistical approach to some differences among the four species related to color and size of the leaves, inflorescences arrangement, and size, surface, and apical shape of the achenes. Hypolytrum longifolium is also morphologically similar to $H$. laxum and $H$. spaherostachyum, which are distinguished by the size of the plants (scape and leaf length), arrangement of the rhizome and size and surface of the achenes.

Representative material examined: BRAZIL. Amazonas. Tefé, Lago Tefé, 11.XII.1982, T. Plowman et al. 12544 (F, INPA, K, MG, NY, US). GUYANA. Cuyuni-Mazaruni: Kanuku Mountains, Moku-Moku Creek, 31.III.1956, A. Smith 3526 (B, BKL, F, G, GH, IAN, K, MO, NY, P, US, W). SURINAME. Marowijne: Moengo Tapoe, Nickerie River, 20.VI.1965, P. Maas et al. 10931 (IAN, MO). 
14. Hypolytrum lucennoi M. Alves \& W.W. Thomas, Feddes Repert. 113: 267. 2002. Type: Bahia, Ubaitaba, 6 Jun 2000, M. Alves, A. Amorim, G. Sousa, A. Prata \& S. Sant'Anna 1964 (holotype CEPEC!, isotypes NY!, SP!).

It is a narrow-endemic species from the state of Bahia (Brazil) in the most diverse area of the central part of the Atlantic Forest for Hypolytrum. It is found on the slopes of shady and humid forests and is considered CR (Critically Endangered) based on the restricted area of occurrence (type locality and surroundings) and very small populations.

Hypolytrum lucennoi can be placed in a morphological group of very robust species (up to $2.5 \mathrm{~m}$ tall) with highly-branched and pyramidal shaped inflorescence and central scape with sessile leaves. It shares these characters with $H$. schraderianum and $H$. verticillatum also found in the Atlantic Forest. It can be recognized by the clustered inflorescences at the end of the $2^{\text {nd }}$ and $3^{\text {rd }}$ order branches, which are reflexed and wrinkled and not reddish-dotted achenes.

Representative material examined: BRAZIL. Bahia: Arataca, Serra Peito de Moça, 23.IX.2006, A. Amorim et al. 6331 (CEPEC, NY); Barro Preto, Serra da Pedra Lascada, 2.XI.2003, P. Fiaschi et al. 1836 (CEPEC, NY); Jaguaquara, road to Apurema, 4.IV.1976, T. Santos et al. 3095 (CEPEC, IPA, NY).

15. Hypolytrum nicaraguense Liebm., Mexic. Halvgr.: 235. 1850. H. longifolium (Rich.) Nees subsp. nicaragunese (Liebm.) T. Koyama, Mem. N.Y. Bot. Gard. 17(1): 75. 1967. Type: Nicaragua. Rio San Juan, s.d., Örsted 14496 (holotype C!, isotype $\mathrm{F}$ !).

= H. corymbosum Rich., Linnaea 37: 125. 1871. nom. nud.

It grows from Central America (Mesoamerica) to northern South America (Amazon Forest), more common on the Caribbean coast than the Pacific (Costa Rica, Panama and Colombia) and up to $500 \mathrm{~m}$ alt. It can be found in the understory of non-flooded and flooded forested areas in Mexico (Veracruz-Llave, Tabasco, Oaxaca, and Chiapas), Belize (Belize, El Cayo, Stann Creek, and Toledo), Guatemala (Petén), Honduras (Atlantida, Colón, and Gracias a Dios), Nicaragua (Atlantico Norte, Atlantico Sur, and Rio San Juan), Costa Rica (Limón and Puntarenas), Panama (Colón, Panamá, and Darién), Colombia (Chocó, Bolivar, Antioquia, Santander, and Vaupés), Venezuela (Zulia, Delta Amacuro, Trujillo, Barinas, Táchira, and Amazonas), Guyana (Pomeroon-Supenaan),
Suriname (Marowijne), and Brazil (Amapá, Amazonas and Pará). It is considered LC (Least Concern) based on its wide distribution and large natural populations.

It has a central scape, sessile leaves and is morphologically similar to $H$. rubescens. It can be recognized by the leaves $(45-90 \times 1.4-3.6 \mathrm{vs}$. $13-40 \times 0.82 .7 \mathrm{~cm}$ in H. rubescens) and cataphylls partially (vs. totally) creamy-reddish on the abaxial surface and achenes (2.4-3.4 vs. 1.9-2.4 mm long) reddish-dotted (vs. non-dotted). Alves (2003) proposed the reestablishment of $H$. nicaraguense and stressed the differences compared to $H$. rubescens, $H$. longifolium, and $H$. sylvaticum.

Representative material examined: BELIZE. Belize: Sibun River, 29.I.1935, P. Gentle 1490 (K, MICH, MO, NY, US). BRAZIL. Amapá: Henrique, station and surroundings, 3.XI.1979, D. Austin 7304 (INPA, MG, NY, US). VENEZUELA. Amazonas: Atures, Puerto Ayacucho, 10.V.1980, J. Steyermark et al. 101968 (MG, MO, NY, VEN).

16. Hypolytrum nudum C.B.Clarke, Kew Bull. Add. Ser. 8: 49. 1908. Type: Guyana. Upper Massaroonie, s.d., Appun 1696 (lectotype K! designated by Koyama, 1970).

Endemic to northwestern South America in the Amazon Forest. It is well collected and found in non-flooded forested areas in Colombia (Guainía and Vaupés), Venezuela (Bolivar and Amazonas), Guyana (Cuyuni-Mazaruni and Potaro-Siparuni), and Brazil (Amazonas). It is considered LC (Least Concern) based on the area of occurrence and the known natural populations.

Hypolytrum nudum has axillary scapes and can be recognized by the sessile leaves, inflorescences branched up to $2^{\text {nd }}$ order, and achenes $4.5-5.5 \mathrm{~mm}$ long with a spongy apex.

Representative material examined: BRAZIL. Amazonas: Tumú, Rio Icanã, 1.IX.1952, R. Fróes 28154 (IAN, UB). GUYANA. Cuyuni-Mazaruni: Chi-Chi Mountains, 18.II.1987, J. Pipoly et al. 10283 (B, MO, NY). VENEZUELA. Bolivar: Ciudade Pilar, Mamaruay Tepui, 3.V.1986, R. Liesner \& B. Holst 20547 (MO, NY).

17. Hypolytrum pallidiceps S. Hooper \& T. Koyama, Bot. Mag. Tokyo 97: 413. 1984. Type: Guyana. Northwestern facing slopes of Mt. Roraima, 24 Mar 1978, Warrington, Burras, Woodhams, \& Edwards, Kew Expedition to Roraima K.E.R. 24. (hototype $\mathrm{NY}$ !, isotypes $\mathrm{K}$ !, $\mathrm{P}$ !, UG).

Endemic to shady and montane areas (700-1,200 m alt.) on Tepuis and eastern Andean slopes in the Amazon Basin. It is known from a 
few samples collected in remote areas, which give insufficient support for an accurate assessment of the conservation status for the species. It is recorded from the Guyana (Cuyuni-Mazaruni) side of the Roraima Mountain Plateau, which is on the border with southern Venezuela and northern Brazil where it probably also grows. It is also known from a single locality in Peru (Amazonas).

It has a central scape, sessile leaves and resembles $H$. puchrum but can be recognized by the membranaceous and curved leaves (vs. rigid and erect), and 4-5 mm long spikes (vs. 8-35 mm long). Representative material examined: GUYANA. Cuyuni-Mazaruni: Pakaraima Mountains, Hoffman \& Henkel 3287 (NY, US). PERU. Amazonas: Bagua, Aguaruna de Wanáa, 18.VI.1996, R. Vásquez et al. 21142 (MO), idem, 29.VIII.1996, C. Diaz et al. 8063 (MO).

18. Hypolytrum paraense M. Alves \& W.W. Thomas, Brittonia 54(2): 133. 2002. Type: Brazil. Pará, Marabá, Serra dos Carajás, 16.X.1977, A. Silva, C. Berg, B. Nelson, A. Henderson, R. Bahia \& M. Santos AS32 (holotype MG!, isotypes INPA!, K!, NY 3x!, RB!, US!).

Endemic and narrow-restricted to some populations in transitional vegetation from nonflooded forest in Serra dos Carajás (state of Pará, Brazil). This area is unique for its rocky soil with high levels of iron and several endemic species (Alves et al. 2003). It is considered CR (Critically Endangered) based on the small area of occurrence (type locality and surroundings), lack of information on the size of populations, and highly intense explotation of mineral sources in the area.

It has a central scape, sessile leaves and is morphologically similar to $H$. supervacuum. It can be recognized by the branched inflorescence and having each spicoid with 3 connate floral bracts and 3 staminate flowers and reddish-dotted achenes.

Representative material examined: BRAZIL. Pará: Marabá, Serra dos Carajás, 28.VI.1976, R. Ribeiro 1408 (IAN, MO), 6 km SE of AMZA camp N-1, 19.V.1982, C. Sperling et al. 5766 (INPA, K, MG, NY), Serra Norte, 30.V.1983, A. Silva et al. 1357 (INPA, MG).

19. Hypolytrum pulchrum (Rudge) H. Pfeiff., Bot. Arch. 12: 450. 1925. Scirpus pulcher Rudge, Pl. Guian.: 18. 1805. Type: Guyana. S.loc., s.d. (lectotype BM!, iconography MO! - designated by Alves et al. 2004).

Endemic to South America, it is found in the Guayana Shield and along coastal sand dunes in northern Brazil with disjunct populations in northeastern Brazil. It is associated with seasonally flooded areas and sandy soils up to $200 \mathrm{~m}$ alt (very seldom $700 \mathrm{~m}$ alt.). It is recorded from Venezuela (Amazonas, Bolivar), Guyana (Cuyuni-Mazaruni, East Berbice-Corentyne, Demerara-Mahaica, Mahaica-Berbice, Potaro-Siparuni, and Upper Tukutu-Upper Essequibo), Suriname (Suriname, Marowijne, and Bokopondo), French Guiana (Saint-Laurent Du Maroni and Cayenne), and Brazil (Amapá, Bahia, and Pará states). It is considered LC (Least Concern) based on the area of occurrence and the size of known natural populations.

It has a central scape, sessile leaves and resembles $H$. rigens and $H$. supervacuum but can be recognized by leaf width $(0.3-0.6 \mathrm{~cm}$ wide), lack of pseudoviviparism, inflorescence often capitate and 3 partially connate floral bracts.

Representative material examined: BRAZIL. Amapá: Calçoene, 30.XI.1984, S. Mori et al. 17095 (F, GH, HAMAB, HUEFS, MG, MICH, MO, NY, UB, US). Bahia: Entre Rios, Rodovia do Coco, 14.VI.2000, M. Alves et al. 2037 (CEPEC, HRB, IAN, MBML, MO, NY, SI, SP, UB, UFP). GUYANA. Potaro Siparuni: Sumara Village, Annai Kurupari, 24.IV.1992, B. Hoffman et al. 1429 (COL, HB, MO, NY, US).

20. Hypolytrum rigens Nees in Mart., Fl. bras. 2(1): 67. 1842. Type: Brazil. Minas Gerais, prope Barreiras in Serra Frio, s.d., Martius 66 (lectotype $\mathrm{M}$ !, isolectotypes GH photo!, M!, US photo! designated by Koyama 1970).

Endemic to Brazil in Cerrado vegetation and usually found associated with rocky outcrops (locally called "Campos Rupestres") from 600 to $1,300 \mathrm{~m}$ alt. It is one of the few species of the genus in the Neotropics that grows outside forest domains. It is found in the states of Bahia, Goiás, Maranhão, Minas Gerais, Piauí, and Tocantins. It is considered VU (Vulnerable) because of the intense expansion of agriculture and mining activities in the Brazilian Cerrado and the medium size of the known populations.

Koyama (1970) considered $H$. rigens as a synonym of $H$. pulchrum which was not accepted by Alves (2003) and Govaerts et al. (2007). Both species are morphologically similar but $H$. rigens can be recognized by the panicle-like inflorescence and free floral bracts, besides the often occurrence of pseudoviviparism and a stoloniferous and highly-branched rhizome.

Representative material examined: BRAZIL. Bahia: Jussiape, road to Ibicoara, 27.I.2000, M. Alves et al. 1836 (CEPEC, IAN, NY, SI, SP, UB, UFP). Goiás: Alto Paraíso 
de Goiás, Parque Nacional da Chapada dos Veadeiros, 17.II.2001, M. Alves et al. 2268 (HTINS, IAN, SP, NY, UB, UFP). Minas Gerais: Grão Mogol, 21.III.1980, G. Hatschbach et al. 42857 (C, ESA, G, INPA, MBM, MO, NY, SP).

21. Hypolytrum rubescens C.B. Clarke, Kew Bull. Add. Ser. 8: 50. 1908. H. longifolium (Rich.) Nees subsp. rubescens (C.B. Clarke) T. Koyama, Mem. N.Y. Bot. Gard. 17(1): 74. 1967. Type: Brazil. (Pará), Rio Capim, s.d., Huber 966 (lectotype MG!, isotypes BM!, F!, G! - designated by Koyama 1967).

Endemic to northwestern South America in the Amazon Forest and well collected and found in non-flooded forest areas in Colombia (Guainía and Vaupés), Venezuela (Delta Amacuro, Táchira, Bolivar, and Amazonas), Guyana (CuyuniMazaruni and Upper Demera-Berbice), and Brazil (Amazonas, Pará, Rondônia, and Roraima). It is considered LC (Least Concern) based on the area of occurrence and the known natural populations.

Hypolytrum rubescens can be recognized by the leaves and cataphylls creamy-reddish on the abaxial surface and achenes (1.9-2.4 mm long) not reddish-dotted and longitudinally wrinkled. Alves (2003) proposed the reestablishment of $H$. rubescens and reinforced that the citation to Panama by Koyama (1970) and Simpson (1998) is a case of misidentification of the specimen Dodge \& Allen 14308 (H. nicaraguense).

Representative material examined: BRAZIL. Amazonas: Hevealândia, Rio Jutaí, 15.X.1974, G. Prance et al. 14318 (F, INPA, K, MG, NY, US). Rondônia: Jaciparanã, Rio Madeira-Jaciparanã, 30.VI.1968, G. Prance et al. 5390 (INPA, K, NY, US). VENEZUELA. Amazonas: San Carlos del Rio Negro, 20.I.1980, R. Liesner et al. 8480 (MO, NY).

22. Hypolytrum schraderianum Nees in Mart., Fl. bras. 2(1): 65. 1842. Type: Brazil. Rio de Janeiro, Ago, Martius 70 (lectotype M! - designated by Koyama 1970).

$=$ H. amplum Poepp. \& Kunth var. $\beta$ Nees in Mart., Fl. bras. 2(1): 65. 1842. H. selloianum Boeck., Linnaea 37: 134. 1871. Type: Brazil. S.loc., s.d., Sellow s.n. (lectotype M! - designated by Alves et al. 2004).

$=H$. microstachyum Boeck., Beitr. Cyper. 1:23. 1888 . Type: Brazil. Rio de Janeiro, s.d., A. Glaziou hb. 11652 (holotype B!, isotypes G!, K!, P!, NY photo!).

$=$ H. macrophyllum Boeck., Allg. Bot. Z. Syst. 5: 78. 1896. Type: Brazil. Rio de Janeiro, Palmeiras, s.d., A. Glaziou 17876 (lectotype F!, isolectotypes F photo!, GH photo!, K!, NY photo!, P! - designated by Alves et al. 2004).
Hypolytrum schraderianum is the most widely distributed and the most collected and common species of the genus in the Neotropics. It is also the only example in Neotropical Hypolytrum of a clear disjunction in forested areas between the Amazon and Atlantic Forests. It is found from southern Central America (Panama) to southern Brazil in shady and humid understory often in seasonally flooded forests up to $900 \mathrm{~m}$ alt. It is recorded from Panama (Colón), Colombia (Chocó, Antioquia, and Vaupés), Venezuela (Bolivar, and Amazonas), Guyana (Barina-Waine), French Guiana (Saint-Laurent Du Maroni), Brazil (Amazonas, Bahia, Espírito Santo, Minas Gerais, Pará, Paraná, Pernambuco, Rio de Janeiro, Roraima, Santa Catarina, and São Paulo), Ecuador (Napo and Pastaza), and probably also in Peru and Suriname. It is considered LC (Least Concern) based on its wide distribution and large natural populations.

Hypolytrum schraderianum is part of a group of robust species with a central scape and sessile leaves. It has a highly-branched and pyramidal inflorescence and can be confused with H. amplissimum, $H$. amplum, $H$. lucennoi, and $H$. verticillatum. The number of branches on the $1^{\text {st }}$ node (4-6) distinguishes it from $H$. verticillatum (14-18 branches) and the spikes not clustered at the end of the axis from H. lucennoi (clustered). The length of the tectriz (16-36 cm long) and floral bracts (1.3-2.1 rarely $2.4 \mathrm{~mm}$ long and connate at least partially) differentiate $H$. schraderianum from H. amplissimum (50-68 cm long; $2.5-3.2 \mathrm{~mm}$ long and free, respectively). Finally, it has shorter spikes (3.5-7 mm long) and spicoid bracts (1.2-1.8 rarely $2.5 \mathrm{~mm}$ long) compared to H. amplum (11-13 mm long and $2.8-3 \mathrm{~mm}$ long, respectively).

Representative material examined: BRAZIL. Amazonas: Manaus, Reserve Ducke, 18.XI.1999, M. Alves \& A. Amorim 1696 (IAN, INPA, NY, SP, UFP). Bahia, Ilhéus, Mata da Esperança, 30.I.2000, M. Alves et al. 1865 (CEPEC, G, IAN, NY, SI, SP, UB, UFP). ECUADOR. Napo: Reserva Faunistico Cuyabeno, 1.III.1990, H. Balslev et al. 97254 (AAU, B, MO).

23. Hypolytrum sphaerostachyum Boeck., Vidensk. Meddel. Nat. Poren. Kjobenhavn 1871: 155. 1871. Type: Brazil. Pará, prov. Obidos, Dec 1849, R. Spruce s.n. (lectotype C!, isolectotypes BM!, G!, GH!, K!, M!, MG!, NY 2x! - designated by Koyama 1970).

Endemic to the Amazon Forest and found in flooded forests and often close to black-water (acid) streams (locally called "igarapés") on white-sand 
soils. It is cited to Colombia (Amazonia), Venezuela (Delta Amacuro, Bolivar, and Amazonas), Brazil (Amazonas, Pará, and Roraima), and Bolivia (Pando). It is considered LC (Least Concern) based on the area of occurrence and the known natural populations.

Hypolytrum sphaerostachyum has a central scape, sessile leaves and is morphologically similar to $H$. laxum. Both species are often misidentified because of the similar habit but it can be recognized by the lightly scabrid keel of the floral bract (vs. strongly scabrid in H. laxum) and non-dotted achene with acute apex (vs. reddish-dotted and contracted apex).

Representative material examined: BOLIVIA. Pando: Abunã, near the river, 14.XI.1968, G. Prance et al. 8415 (GH, INPA, K, MG, NY, P, R, US). BRAZIL. Amazonas: Lábrea, Rio Purus, 25.VI.1971, G. Prance et al. 13655 (F, GH, INPA, K, M, NY, P, R, US). VENEZUELA. Amazonas: Rio Casiquiare, Isla San Sebastian, 31.I.1980, R. Liesner \& H. Clarke 8951 (MO, NY).

24. Hypolytrum spongiosum T. Koyama, Mem. N.Y. Bot. Gard. 17(1): 76. 1967. Type: Venezuela. Amazonas, Alto Rio Orinoco, base of Cerro Yapacanã, 16.IX.1957, B. Maguire, J. Wurdack \& W. Keith 41504 (holotype NY!, isotypes K!, NY!, SI photo!).

Endemic to the Amazon Forest in seasonally flooded and non-flooded forested areas and recorded from Colombia (Vaupés and Amazonas), Venezuela (Amazonas), Guyana (Cuyuni-Mazaruni), and Brazil (Amazonas and Rondônia). It is considered LC (Least Concern) based on the area of occurrence and the known natural populations.

Hypolytrum spongiosum has axillary scapes, sessile leaves and can be recognized by having 3-9 (seldom 2-1) spikes in each scape and achenes 3-4.2 $\mathrm{mm}$ long and a spongy apex. It differs from $H$. strictum by the number of spikes and size of the achenes and from H. nudum, which shares achenes with a spongy apex, by the unbranched inflorescence.

Representative material examined: BRAZIL. Amazonas: São Felipe, Igarapé Imutã, 18.III.1952, $R$. Fróes 27942 (IAN, MO, SI, UB). Rondônia: Jaciparanã, road to Porto Velho, 29.VI.1968, G. Prance et al. 5326 (INPA, K, NY, R). VENEZUELA. Amazonas: Rio Yatuã, Cerro Arauicanã, 11.IV.1970, J. Steyermark \& G. Bunting 102549 (MO, NY, VEN).

25. Hypolytrum stemonifolium T. Koyama, Jap. J. Bot. 20(2): 129. 1969. Type: Brazil. Pará, Aracá Mountains, 18.XI.1952, Forest Dept. British Guyana Record (N. Guppy G607) n. 7622 (holotype NY!, isotypes K!, SI photo!).
Endemic to the Amazon Forest in nonflooded forested areas and only recorded so far from Brazil (Amazonas, Pará, and Rondônia), but possibly to be found in southern Guyana and northeastern Bolivia as well. It is considered LC (Least Concern) based on the area of occurrence and the known natural populations.

Hypolytrum stemonifolium is recognized by the elliptical to oblong and sometimes lightly bullate leaves $(10-19 \times 2-3.8 \mathrm{~cm})$ with acuminate apex, short pseudopetiole, central scape and achenes with a spongy apex. The leaves in this species are usually found only along the scape and the base of the plant is covered by reddish, papery cataphylls up to $6 \mathrm{~cm}$ long.

Representative material examined: BRAZIL. Amazonas: Itapiranga, Rio Uatumã, 25.VIII.1979, C. Ferreira et al. 804 (INPA, NY). Pará: Oriximiná, Rio Piauí do Oeste, 9.VIII.1980, C. Ferreira et al. 2341 (INPA, NY). Rondônia: Mutumparanã, Rio Madeira, 23.XI.1968, G. Prance et al. 8778 (INPA, K, MG, NY, US).

26. Hypolytrum strictum Poepp. \& Kunth, Enum. pl. 2: 270. 1837. Type: Brazil. (Amazonas), prope Ega, ad fluvium Amazonum, s.d., Poeppig (2573) (lectotype F!, isotypes F photo!, US! - designated by Alves et al. 2004).

$=H$. scapigerum Nees in Mart., Fl. bras. 2(1): 69. 1842. Type: Brazil. (Amazonas), Rio Negro, sylvacis ad Barra, s.d., Martius 138 (holotype M!, isotypes F photo!, GH!, US!).

$=H$. micranthum Boeck., Vidensk. Meddel. Dansk. Naturhist. Kjobenhaven 8-10: 154. 1871. Type: Brazil. (Amazonas), prope Barra, prov. Rio Negro, s.d., Spruce 1793 (holotype C!, isotypes BM!, G!, GH!, INPA photo!, K!, MG!, NY!, NY photo!, P!, S!, SI photo!, US photo!).

Endemic to the western part of the Amazon Forest in non-flooded forested areas and recorded from Venezuela (Amazonas), Brazil (Amazonas), Ecuador (Napo), Peru (Loreto), Bolivia (Pando), and probably Colombia as well. It is considered LC (Least Concern) based on the area of occurrence and the known natural populations.

Hypolytrum strictum has axillary scapes and is morphologically similar to $H$. spongiosum but can be recognized by having fewer spikes per inflorescence (1-2, very seldom 3 vs. 3-9 very seldom 2) and shorter achenes (1.7-2.2 $\mathrm{mm}$ long vs. 3-4.2 mm long).

Representative material examined: BOLIVIA. Pando: Abunã, near Rio Madeira, 11.VII.1968, G. Prance et al. 5869 (COL, GH, F, INPA, K, MG, NY, 
R, US). BRAZIL. Amazonas: Manaus. Cachoeira do Tarumanzinho, 4.II.1963, G. Eiten et al. 5325 (K, MO, NY, SP, UB). PERU. Loreto: Rio Mamon, near Nanay River, 1.IX.1975, T. Croat et al. 19935 (GH, NY, MO).

27. Hypolytrum supervacuum C.B. Clarke, Kew Bull. Add. Ser. 8: 50. 1908. Type: Brazil. Pará, in vicinibus Óbidos, s.d., R. Spruce 475 (holotype $\mathrm{BM}$ !, isotypes B!, G!, K!, M!, NY!, NY photo!, P photo!, SI!, US!).

Endemic to the northern part of the Amazon Forest and almost restricted to the Guayana Shield where it is often associated with sandy patches in non-flooded forested areas. It is recorded from Venezuela (Amazonas), Guyana (Upper TakutuUpper Essequibo), Brazil (Amapá, Amazonas, Pará, and Rondônia), and probably also occurs in French Guiana, Suriname, and Bolivia. It is considered LC (Least Concern) based on the area of occurrence and the known natural populations.

Alves (2003) indicated the isotypes at B, $\mathrm{BM}, \mathrm{G}$ and $\mathrm{M}$ based on the locality, collector and the handwriting of the author of the species. Hypolytrum supervacuum has a central scape, sessile leaves and can be misidentified as $H$. paraense, $H$. pulchrum and $H$. rigens. However, it is recognized by the leaves $(30-70 \times 0.7-0.9 \mathrm{~cm})$, lax inflorescence, elliptical achenes $2.3-3 \mathrm{~mm}$ long, and lack of pseudoviviparism.

Representative material examined: BRAZIL. Amapá: Matapi, 26.XI.1976, B. Ribeiro 1622 (F, HRB, MG, MO). Amazonas: Presidente Figueiredo, road to Balbina, 3.IX.1979, C. Ferreira et al. 980 (INPA, NY, US). VENEZUELA. Amazonas: Atures, Rio Cataniapo, 10.V.1980, J. Steyermark et al. 122228 (MO, NY).

28. Hypolytrum sylvaticum Kunth, Enum. pl. 2: 270. 1837. H. longifolium subsp. sylvaticum (Kunth) T. Koyama, Mem. N.Y. Bot. Gard. 17(1): 74. 1967. Type: Brazil. (Amazonas), prope Ega, ad fluvium Amazonum, s.d., Poeppig (2574) (lectotype G!, isolectotypes BM!, GH!, P! designated by Alves et al. 2004).

= H. punctatum Nees in Mart., Fl. bras. 2(1): 66 . 1842. Type: Brazil. (Amazonas), prov. Fl. Nigris, ad Ega, Martius 102 (lectotype M! - designated by Koyama 1970).

It is widely distributed in the Amazon Forest and probably up to southern Panama in shady and humid understory of non-flooded forests up to $300 \mathrm{~m}$ alt. It is recorded from Colombia (Chocó, Antioquia, Meta, Vaupés, and Amazonas), Venezuela (Delta Amacuro, Bolivar, and Amazonas), Guyana (Cuyuni-Mazaruni, Essequibo Islands-West Demerara, Potaro Siparuni, Upper Demerara-Berbice, and Upper TukutuUpper Esequibo), Suriname (Marowijne), French Guiana (Cayenne), Brazil (Amapá, Amazonas, Pará, and Roraima), Ecuador (Napo), Peru (Loreto, Pasco), and probably occurs in northeastern Bolivia and southern Panama as well. It is considered LC (Least Concern) based on its wide distribution and large natural populations.

Hypolytrum sylvaticum has a central scape and sessile leaves. It was cited by Koyama (1970) and Govaerts et al. (2007) as one of the subspecies of H. longifolium. Alves (2003) considered the taxon at the species level, using as diagnostic characters leaves (0.9-1.7 cm wide) dark-green in both surfaces and achenes reddish-dotted and wrinkled. It can be found growing together with H. schraderianum, which is a more robust species $(1.2-2 \mathrm{~m}$ tall) and has highly-branched and pyramidal inflorescences.

Representative material examined: BRAZIL. Amazonas: Humaitá, road to Porto Velho, 1.XII.1966, G. Prance et al. 3516 (F, INPA, K, MO, NY, R, US). GUYANA. Essequibo Islands-West Demerara: Essequibo River, Onoro Creek, 15.XII.937, A. Smith 2656 (BKL, G, GH, F, K, MO, NY, P). VENEZUELA. Bolivar: Gran Sabana, Asa River, 17.V.1987, G. Aymard 6096 (MO, NY, PORT).

29. Hypolytrum verticillatum $\mathrm{T}$. Koyama, Darwiniana 16(1-2): 75. 1970. Type: Brazil. Rio de Janeiro, Campos, Lagoa Feia, 12.IX.1953, F. Segadas-Vianna, L. Dau, W. Ormond, G. Machine \& J. Lodedo Jr. Restinga I-4 (holotype R!, isotypes NY photo!, SI!, US photo!).

Endemic to a narrow stretch along the coast from southern state of Bahia to northern Rio de Janeiro, including Espírito Santo, Brazil. It grows in large and dense populations in permanently to seasonally flooded forest with dark-ferruginous water in sand dune vegetation called locally "restingas". It is considered VU (Vulnerable) because it is endemic to one of the most fragile vegetation types of the Atlantic Forest along the Brazilian coast with the highest level of destruction and pollution of the natural habitat from human occupation.

Hypolytrum verticillatum has a central scape, sessile leaves and shares the robust habit and highly branched inflorescence with $H$. lucennoi and $H$. schraderianum among other species from the Atlantic Forest. However, H. schraderianum also grows in seasonally flooded areas, the species 
can be distinguished by the number of branches on the basal (lower) node of the inflorescence (14-18 in $H$. verticillatum vs. 8-12 seldom up to 14 in $H$. schraderianum) and the achenes (3.8-4.6 $\mathrm{mm}$ long, smooth and not reddish-dotted vs. $2-3.3 \mathrm{~mm}$ long, wrinkled and reddish-dotted).

Representative material examined: BRAZIL. Bahia: Alcobaça, BR-255, 17.IX.1978, S. Mori et al. 10618 (CEPEC, NY). Porto Seguro, Reserva Particular do Patrimônio Natural Aracruz Celulose, 23.VIII.1993, L. Guedes et al. 2961 (ALCB, SPF). Espírito Santo: Guarapari: Parque Estadual Paulo César Vinha, 13.II.2000, M. Alves et al. 1916 (NY, UFP, VIES).

\section{Acknowledgements}

Financial support for field work resulting in collections of this genus was provided by the John D. and Catherine T. MacArthur Foundation, the National Science Foundation, and the Beneficia Foundation. We thank the curators of the herbaria we consulted, CAPES, CNPq and the Mellon Foundation for the fellowships, and Scott Heald for the English review.

\section{References}

Alves, M. 2003. Hypolytrum Rich. (Cyperaceae) nos Neotrópicos. Doctoral Thesis, Universidade de São Paulo, São Paulo. 167p.

Alves, M.; Araujo, A.C.; Prata, A.A.; Vitta, F.; Hefler, S.; Trevisan, R.; Gil, A.S.B.; Martins, S. \& Thomas, W. 2009. Diversity of Cyperaceae in Brazil. Rodriguesia 60: 771-782.

Alves, M.; Estelita, M.E.M.; Wanderley, M.G.L. \& Thomas, W. 2002c. Aplicações taxonômicas da anatomia foliar das espécies brasileiras de Hypolytrum Rich. Cyperaceae. Revista Brasileira de Botânica 25: 1-9.

Alves, M.; Wanderley, M.G.L. \& Thomas, W. 2001. Typology of the inflorescence in species of Hypolytrum Rich. (Cyperaceae) from Brazil. Beitrage Biologie Pflanzen 72: 59-73.

Alves, M.; Wanderley, M.G.L. \& Thomas, W.W. 2002a. Four new species of Hypolytrum Rich. (Cyperaceae) from Costa Rica and Brazil. Feddes Repertorium 113: 261-270.

Alves, M.; Wanderley, M.G.L. \& Thomas, W.W. 2002 b. New species of Hypolytrum Rich. (Cyperaceae) from the Neotropics. Brittonia 54: 60-71.

Alves, M.; Wanderley, M.G.L. \& Thomas, W.W. 2003. Padrões de distribuição das espécies neotropicais de Hypolytrum (Cyperaceae). Boletim de Botânica da Universidade de São Paulo 21: 265-276.

Alves, M.; Wanderley, M.G.L. \& Thomas, W.W. 2004. Lectotypifications in Neotropical Hypolytrum Rich. (Cyperaceae). Taxon 53: 551-552.
Alves, M.; Hefler, S.M.; Trevisan, R.; Silva Filho, P.J.S. \& Ribeiro, A.R.O. 2014. Cyperaceae. In: Lista de Espécies da Flora do Brasil. Jardim Botânico do Rio de Janeiro. Availabe at $<$ http://floradobrasil.jbrj.gov. br/>. Access on 20 October 2014.

Bruhl, J. 1995. Sedge genera of the world: relationships and new classification. Australian Journal of Botany 8: 125-305.

Camelbecke, K.; Goetghebeur, P.; González-Eliazondo, M.S.; Kerns, D.M.; Kral, R.; Reznicek, A.A.; Simpson, D.A.; Strong, M.T.; Thomas, W.W. \& Turcker, G.C. 2007. Cyperaceae. In: Kunk, V.; Hallowell, T.; Berry, P.; Kelloff, C. \& Alexander, S.N. (orgs.). Checklist of the plants of the Guayana Shield. Washington Museum of Natural History, Washington. Pp. 88-103.

Charpin, A.; Alves, M. \& Luceno, M. 1993. Tipificaciones de Cyperaceae tropicales de los herbários de Genebra. Candollea 48: 469-473.

Coan, A.I.; Alves, M. \& Scatena, V.L. 2008. Comparative study of ovule and fruit development in species of Hypolytrum and Rhynchospora (Cyperaceae, Poales). Plant Systematics and Evolution 272: 181-195.

Coan, A.I.; Alves, M. \& Scatena, V.L. 2010. Evidence of pseudomonad pollen formation in Hypolytrum (Mapanioideae, Cyperaceae). Australian Journal of Botany 58: 663-672.

Goetghebeur, P. 1998. Cyperaceae. In: Kubitzki, K.; Huber, H.; Rudall, P.; Stevens, P. \& Stützel, T. (orgs.). Vascular flowering plants. Vol. 4. Springer, Berlin. Pp. 141-189.

Gómez-Laurito, J. 1994. Hypolytrum. In: Davidse, G.; Sousa, M. \& Chater, A. (orgs.). Flora Mesoamericana. Vol. 6. Universidad Nacional Autônoma de Mexico, Mexico DF. Pp. 474-475.

Gómez-Laurito, J. 2003. Cyperaceae. In: Hammel, B.E.; Grayum, M.H.; Herrera, C. \& Zamora, N. (eds.). Manual de las plantas de Costa Rica. Monographs in Systematic Botany, Missouri Botanical Garden 93: 458-551.

Govaerts, R.; Simpson, D.A.; Bruhl, J.; Egorova, T.; Goetghebeur \& Wilson, K. 2007. World checklist of Cyperaceae. Kew Gardens, London. 765p.

IUCN. 2012. The IUCN Red List of Threatened Species. Version 2012.2. Available at $<$ http://www. iucnredlist.org > . Access on 20 May 2014.

Koyama, T. 1966. The systematic significance of the leaf structure in Cyperaceae-Mapanieae. Memoirs of the New York Botanical Garden 15: 136-159.

Koyama, T. 1969. Delimitation and classification of Cyperaceae-Mapanioideae. Current Topics in Plant Science 4: 201-228.

Koyama, T. 1970. The American species of the genus Hypolytrum (Cyperaceae). Darwiniana 16: 49-92.

Mittermeier, R.A.; Gil, P.R.; Hoffman, M.; Pilgrim, J.; Brooks, T.; Mittermeier, C.G.; Lamoreaux, J. \& 
Fonseca, G.A.B. 2005. Hotspots revisited: earth's biologically richest and most threatened terrestrial ecoregions. Conservation International, Monterrey. $391 p$.

Muasya, A.M.; Bruhl, J.; Simpson, D.A.; Culham, A. \& Chase, M.W. 2000. Suprageneric phylogeny of Cyperaceae: a combined analysis. In: Wilson, K. \& Morrison, D. (eds.). Monocots: Systematics and Evolution. CSIRO, Melbourne. Pp.: 593-601.

Muasya,A.M.; Simpson, D.A.; Chase, M.W. \& Culham. A. 1998. An assessment of the suprageneric phylogeny in Cyperaceae using $r b c \mathrm{~L}$ DNA sequences. Plant Systematic and Evolution 211: 257-271.

Muasya, A.M.; Simpson, D.A.; Verboom, G.A.; Goetghebeur, P.; Naczi, R.F.C.; Chase, M.W. \& Smets, E. 2009. Phylogeny of Cyperaceae based on DNA sequence data: current progress and future prospects. Botanical Review 75: 2-21.

Rodrigues, A.C. \& Estelita, M.E.M. 2009. Morphoanatomy of the stem in some Cyperaceae. Acta Botanica Brasilica 23: 889-901.

Silva, A.L.; Alves, M.V.S. \& Coan, A.I. 2014. Importance of anatomical leaf features for characterization of three species of Mapania (Mapanioideae, Cyperaceae) from the Amazon Forest, Brazil. Acta Amazonica 44: 447-456.
Simpson, D.A. 1992. A revision of the genus Mapania. Kew Gardens, London. 189p.

Simpson, D.A. 1996. New taxa and combination in Mapania (Cyperaceae) from South America. Kew Bulletin 51: 729-740.

Simpson, D.A. 1998. Hypolytrum. In: Steyermark, J.A.; Berry, P.E. \& Holst, B.K. (orgs.). Flora of the Venezuelan Guayana. Vol. 4. Missouri Botanical Garden, St. Louis. Pp. 579-586.

Simpson, D.A.; Furness, C.A.; Hodkinson, T.R.; Muasya, A.M. \& Chase, M.W. 2003. Phylogenetic relationships in Cyperaceae subfamily Mapanioideae inferred from pollen and plastid DNA sequence data. American Journal of Botany 90: 1071-1086.

Simpson, D.A.; Muasya, A.M.; Alves, M.V.; Bruhl, J.J.; Dhooge, S.; Chase, M.W.; Furness, C.A.; Ghamkhar, K.; Goetghebeur, P.; Hodkinson, T.R.; Marchant, A.D.; Reznicek, A.A.; Nieuwborg, R.; Roalson, E.H.; Smets, E.; Starr, J.R.; Thoms, W.W.; Wilson, K.L. \& Zhang, X. 2007. Phylogeny of Cyperaceae based on DNA sequence data - a new $r b c \mathrm{~L}$ analysis. Aliso 23: 72-83.

Uittien, H. 1925. Cyperaceae. In: Pulle, A. (ed.). Neue Beiträage zur Flora Surinameensis IV. Recueil des Traveaux Botanique Neerlandais 22: 334-344. 